\title{
Foliar Nutrition of Serianthes nelsonii Seedlings as a Conservation Tool
}

\author{
Thomas E. Marler \\ Western Pacific Tropical Research Center, University of Guam, Mangilao, \\ GU 96923 \\ Additional index words. conservation biology, endangered plants, Guam, nutrient resorption
}

\begin{abstract}
Conservation of the endangered Serianthes nelsonii is constrained by lack of research. Transplanted containerized plants die in the competitive in situ environment. This study determined if foliar applications of nutrient solution could replace edaphic fertilizer applications for mitigating competition for soil nutrients. Weekly sprays with $0.1 \times$ Hoagland solution were compared with weekly drenches of $0.5 \times$ Hoagland solution. Plants receiving edaphic or foliar nutrition were not different in height, and height growth was $72 \%$ above that of control plants. Similar results were obtained for stem diameter and leaf number. Leaf nutrient concentrations were not different for the two nutrition treatments, but stem nutrient concentration differences were dependent on the element. Stem copper, nitrogen, phosphorus, potassium, and zinc concentrations were not different for edaphic vs. foliar nutrition. Contrarily, stem boron, calcium, iron, magnesium, and manganese concentrations were greater in plants receiving edaphic nutrients. The results indicate nutritional needs of recently out-planted plants may be supplied directly to leaves to mitigate below-ground competition for nutrient resources.
\end{abstract}

Conservation of the endangered $S$. nelsonii has suffered from a history of limited research (Marler et al., 2021). A chronic conservation failure has been mortality of container-grown plants after transplanting to in situ forests. Limited root growth at the time of transplanting (Marler, 2019) and competition for resources in this biodiverse setting (Marler and Musser, 2015) have been identified as causes of in situ seedling mortality.

Mineral nutrients are derived from the soil, and soil-applied fertilizers form the foundation of horticultural mitigation of deficiencies. Under some conditions, these added nutrients may become unavailable to the managed plants due to soil characteristics or plant competition. Foliar applications and trunk injections of nutrients have been used to mitigate these conditions. This study determined if foliar applications of nutrient solutions to $S$. nelsonii seedlings could generate growth and tissue concentrations similar to soil-applied solutions.

\section{Methods}

The study was conducted in a conservation nursery in Angeles City, Philippines. The seedlings were sourced from urban street trees on Rota Island, and original provenance was not known. The seedlings were initially grown in tubes (5-cm diameter, 12-cm depth)

Received for publication 18 Nov. 2021. Accepted for publication 17 Dec. 2021.

Published online 28 January 2022.

T.E.M. is the corresponding author. E-mail: marler.uog@gmail.com.

This is an open access article distributed under the CC BY-NC-ND license (https://creativecommons. org/licenses/by-nc-nd/4.0/). and were $27.8 \pm 1.1 \mathrm{~cm}$ tall $($ mean $\pm \mathrm{SE}$ ) with a basal diameter of $5.1 \pm 0.2 \mathrm{~mm}$ at the initiation of the study. Seedlings were bare-rooted on 5 Nov. 2017 and planted individually in 2.6- $\mathrm{L}$ containers in a medium composed of one-third loam soil and two-thirds quarried river sand. The soil ensured a suite of nutrients to sustain limited growth of control plants, and the sand ensured adequate drainage in the containers. This substrate was impoverished, as indicated by soil analyses that revealed total nitrogen was $4.9 \pm 0.2 \mathrm{mg} \cdot \mathrm{g}^{-1}$, available phosphorus was $5.9 \pm 0.5 \mathrm{mg} \cdot \mathrm{kg}^{-1}$, and exchangeable potassium was $29.6 \pm 1.6 \mathrm{mg} \cdot \mathrm{kg}^{-1}$ (mean \pm SE, $n=4$ ).

The plants were sorted into three treatments. Control plants received no nutritional applications. Plants in the foliar treatment received weekly sprays of $0.1 \times$ Hoagland solution. Every fully expanded leaf was sprayed using the standard horticultural protocol of application until initial runoff. Plants in the soil-applied treatment received weekly drenches of $0.5 \times$ Hoagland solution. Each container received $200 \mathrm{~mL}$ of solution. Daily irrigation using deep well water was provided with care to refrain from wetting the leaf surfaces. Initial plant height and basal stem diameter were measured. The plants were grown under $50 \%$ shadecloth and rainfall protection until 15 Jan. 2018.

Ending height, basal stem diameter, and leaf number were measured. The terminal 15 $\mathrm{cm}$ of each stem was pruned and separated into stem and leaf tissues. All tissue was washed four times in reverse osmosis water to remove all nutrients adhering to the organ surfaces. Nutrient concentrations were quantified using previously described methods (Marler, 2021). The tissue was dried at $75^{\circ} \mathrm{C}$ for $24 \mathrm{~h}$ and milled to pass through 20-mesh screen. Total carbon and nitrogen were determined by dry combustion (FLASH EA1112 CHN Analyzer; Thermo Fisher, Waltham, MA). Samples were digested by a microwave system with nitric acid and peroxide, then boron, calcium, copper, iron, magnesium, manganese, phosphorus, potassium, and zinc were quantified by inductively coupled plasma optical emission spectroscopy (Spectro Genesis; SPECTRO Analytical Instruments, Kleve, Germany).

Each response variable was subjected to one-way analysis of variance (Proc GLM; SAS Institute, Cary, NC). Growth was calculated as the difference in height and stem diameter from the initial to the final measurements. Tukey's honestly significant difference was used for pairwise comparisons for significant response variables.

\section{Results}

Growth was similar for plants receiving the two nutrient application treatments (Fig. 1). The increase in height was $72 \%$ above, increase in diameter was $29 \%$ above, and ending leaf number was $64 \%$ above that of control plants.

Leaf nutrient concentrations were not different between the two nutrition treatments, but one or both treatments exhibited leaf concentrations greater than control plants for eight of the 11 nutrients (Table 1). The exceptions were boron, carbon, and copper.

Stem nutrient concentration differences were heterogeneous among the nutrients (Table 1). Stem boron, copper, nitrogen, phosphorus, potassium, and zinc concentrations were not different for edaphic vs. foliar nutrition. In contrast, stem calcium, iron, magnesium, and manganese concentrations were greater in plants receiving edaphic applications than plants receiving foliar applications. As expected, most of the nutrients in stems of the plants receiving edaphic applications were greater than stems of control plants. In addition, eight of the 11 nutrients exhibited greater stem concentrations for the foliar application treatments than for the control treatment.

\section{Discussion}

The results indicate nutritional needs of recently out-planted $S$. nelsonii plants may be supplied as sprays to aboveground organs to mitigate the below-ground competition for nutrient resources. Phosphorus and potassium limit in situ $S$. nelsonii productivity more than other nutrients based on leaf stoichiometry (Marler, 2021). Plants receiving the foliar applications exhibited leaves with $56 \%$ greater phosphorus and 35\% more potassium than control plants. More importantly, plants receiving foliar applications exhibited stems with $75 \%$ more phosphorus and $45 \%$ more potassium than control plants, indicating efficient mobilization of foliar-applied nutrients into the stem tissue.

Nitrogen, phosphorus, potassium, and zinc are resorbed in senescing $S$. nelsonii leaves more efficiently than other nutrients (Marler, 2021). Although the control plants in this study exhibited leaf mortality, no leaf mortality 

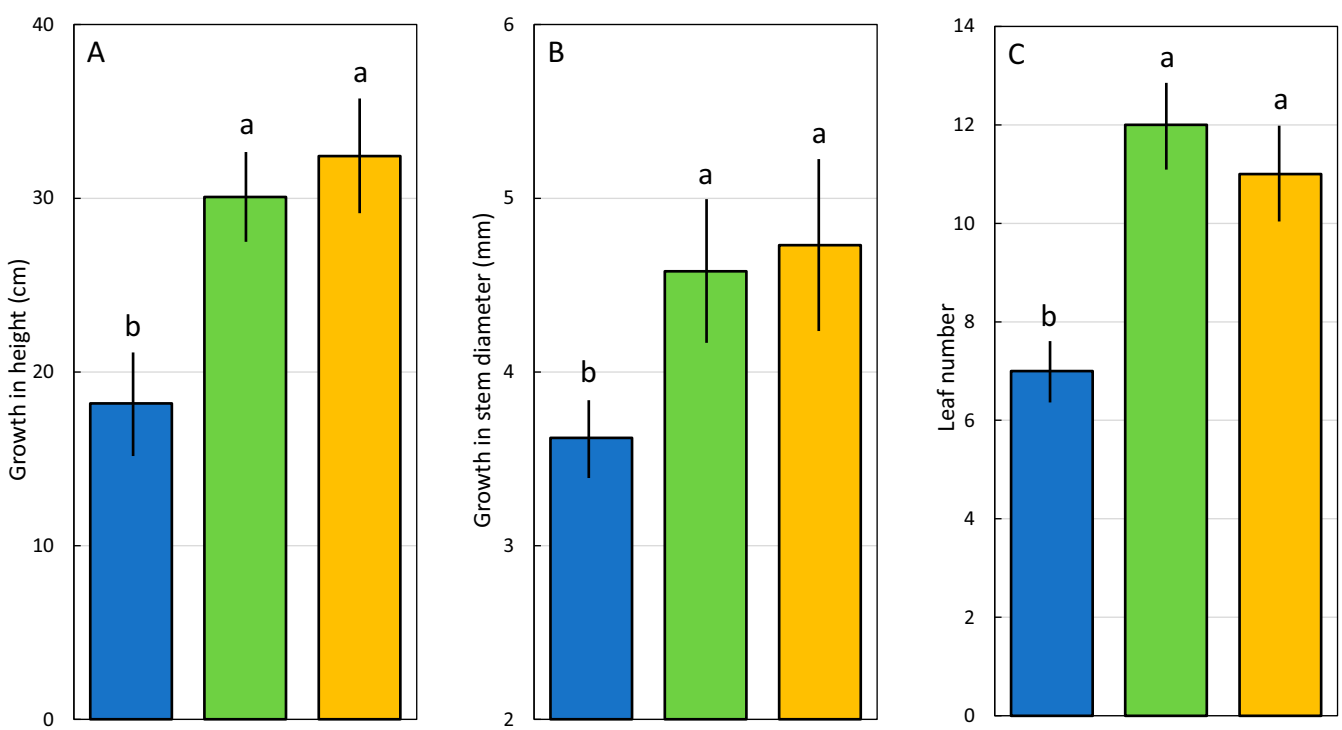

Fig. 1. Size of Serianthes nelsonii seedlings as influenced by nutrition treatments. Blue $=$ control; green $=$ edaphic nutrition; yellow $=$ foliar nutrition.

(A) Increase in stem height; (B) increase in stem diameter; (C) final leaf number. Bars with same letters are not different. Mean $\pm \mathrm{SE}, \mathrm{n}=8$.

occurred in the nutrient application treatments. The substantial increase in stem concentrations of these nutrients deserves further study, as the results indicate translocation from leaf to stem occurred in the absence of leaf senescence. The observation that leaf longevity increased in plants receiving either nutrient treatment also deserves further study as one approach for increasing plant productivity.

The mechanistic details of these plant behaviors may be more fully understood with more refined methods; for example, use of solution applications that ensure homogeneous total nutrient applications between the two treatments. Moreover, endorsement of this conservation protocol requires repeating the methods in situ. One caveat of my methods is that rainfall was excluded from the experimental plants. This is not feasible in a forest setting. Rainfall may affect the results in two ways. First, tissue concentrations may be less than reported here if nutrients are washed off by rainfall before absorption into the laminae. Second, tissue concentrations may be more than reported here if some surface nutrients are washed into the soil where they may be absorbed by the roots. Moreover, plant responses to horticultural manipulations may be affected by con- and interspecific competition, so the efficacy of this newly described management protocol in situ is not known until it is repeated in a competitive forest.

This study adds to a growing body of adaptive management lessons that inform conservation decisions for this endangered

Table 1. Foliar and stem nutrient concentrations of Serianthes nelsonii seedlings as influenced by edaphic versus foliar nutrition. Mean $\pm \mathrm{SE}, \mathrm{n}=8$.

\begin{tabular}{lcccrr}
\hline Nutrient & Control & Edaphic nutrition & Foliar nutrition & $F_{2,21}$ & $P$ \\
\hline Leaf & & & & & \\
$\quad$ Boron & $33.1 \pm 1.6 \mathrm{a}^{\mathbf{z}}$ & $35.1 \pm 1.9 \mathrm{a}$ & $35.7 \pm 1.7 \mathrm{a}$ & 0.726 & 0.496 \\
Calcium & $10.6 \pm 0.5 \mathrm{~b}$ & $12.1 \pm 0.6 \mathrm{ab}$ & $12.8 \pm 0.8 \mathrm{a}$ & 4.997 & 0.017 \\
Carbon & $447 \pm 3 \mathrm{a}$ & $452 \pm 2 \mathrm{a}$ & $450 \pm 2 \mathrm{a}$ & 1.474 & 0.252 \\
Copper & $2.5 \pm 0.3 \mathrm{a}$ & $2.9 \pm 0.3 \mathrm{a}$ & $3.1 \pm 0.3 \mathrm{a}$ & 1.209 & 0.318 \\
Iron & $38.8 \pm 2.8 \mathrm{~b}$ & $59.1 \pm 4.2 \mathrm{a}$ & $57.1 \pm 5.3 \mathrm{a}$ & 7.772 & 0.003 \\
Magnesium & $2.1 \pm 0.1 \mathrm{~b}$ & $2.9 \pm 0.1 \mathrm{a}$ & $2.8 \pm 0.1 \mathrm{a}$ & 19.557 & $<0.001$ \\
Manganese & $24.1 \pm 1.9 \mathrm{~b}$ & $32.4 \pm 3.4 \mathrm{a}$ & $33.9 \pm 3.5 \mathrm{a}$ & 3.547 & 0.047 \\
Nitrogen & $15.1 \pm 1.0 \mathrm{~b}$ & $22.5 \pm 1.5 \mathrm{a}$ & $21.2 \pm 1.2 \mathrm{a}$ & 9.976 & $<0.001$ \\
Phosphorus & $1.6 \pm 0.1 \mathrm{~b}$ & $2.6 \pm 0.1 \mathrm{a}$ & $2.5 \pm 0.1 \mathrm{a}$ & 30.798 & $<0.001$ \\
Potassium & $11.2 \pm 0.4 \mathrm{~b}$ & $14.8 \pm 0.5 \mathrm{a}$ & $15.1 \pm 0.6 \mathrm{a}$ & 21.904 & $<0.001$ \\
Zinc & $20.4 \pm 1.9 \mathrm{~b}$ & $36.6 \pm 2.5 \mathrm{a}$ & $36.4 \pm 2.8 \mathrm{a}$ & 14.847 & $<0.001$ \\
Stem & & & & & \\
Boron & $9.7 \pm 0.3 \mathrm{~b}$ & $11.7 \pm 0.7 \mathrm{a}$ & $10.4 \pm 0.5 \mathrm{ab}$ & 10.265 & $<0.001$ \\
Calcium & $15.1 \pm 1.1 \mathrm{a}$ & $14.7 \pm 0.3 \mathrm{a}$ & $11.7 \pm 0.2 \mathrm{~b}$ & 8.480 & 0.002 \\
Carbon & $426 \pm 1.8 \mathrm{a}$ & $427 \pm 2 \mathrm{a}$ & $433 \pm 3 \mathrm{a}$ & 3.369 & 0.058 \\
Copper & $3.1 \pm 0.3 \mathrm{a}$ & $4.0 \pm 0.8 \mathrm{a}$ & $3.9 \pm 0.3 \mathrm{a}$ & 1.452 & 0.257 \\
Iron & $42.8 \pm 2.5 \mathrm{a}$ & $44.5 \pm 3.5 \mathrm{a}$ & $29.4 \pm 1.2 \mathrm{~b}$ & 3.986 & 0.034 \\
Magnesium & $2.4 \pm 0.1 \mathrm{~b}$ & $3.1 \pm 0.2 \mathrm{a}$ & $2.5 \pm 0.1 \mathrm{~b}$ & 11.089 & $<0.001$ \\
Manganese & $5.2 \pm 0.3 \mathrm{~b}$ & $6.8 \pm 0.4 \mathrm{a}$ & $5.1 \pm 0.4 \mathrm{~b}$ & 6.345 & 0.007 \\
Nitrogen & $5.7 \pm 0.6 \mathrm{~b}$ & $8.8 \pm 1.0 \mathrm{a}$ & $8.7 \pm 0.4 \mathrm{a}$ & 6.725 & 0.006 \\
Phosphorus & $1.6 \pm 0.2 \mathrm{~b}$ & $2.7 \pm 0.1 \mathrm{a}$ & $2.8 \pm 0.1 \mathrm{a}$ & 21.821 & $<0.001$ \\
Potassium & $10.4 \pm 0.1 \mathrm{~b}$ & $14.9 \pm 0.8 \mathrm{a}$ & $15.1 \pm 0.7 \mathrm{a}$ & 18.672 & $<0.001$ \\
Zinc & $24.1 \pm 1.4 \mathrm{~b}$ & $37.5 \pm 4.3 \mathrm{a}$ & $34.5 \pm 2.7 \mathrm{a}$ & 5.481 & 0.012 \\
\hline zeans within a row not followed by the same letter are significantly different at $P \leq 0.05$ &
\end{tabular}

${ }^{\mathrm{z}}$ Means within a row not followed by the same letter are significantly different at $P \leq 0.05$.

endemic tree species (Marler et al., 2021). For example, treatments that increase relative root growth in a container nursery appear to be mandatory to improve posttransplant survival, and two protocols have been identified to achieve this goal (Marler, 2019; Marler and Callaway, 2021). As a late successional species, studies indicate shade is mandatory for germination and growth of seedlings and saplings (Marler et al., 2015). Grafting scions on congeneric rootstocks may be used to mitigate the constrained seed supply (Marler, 2017).

\section{Literature Cited}

Marler, T.E. 2017. Asexual reproduction to propel recovery efforts of the critically endangered Håyun Lågu tree (Serianthes nelsonii Merr.). Trop. Conserv. Sci. 10:1-10, https://doi.org/ 10.1177/1940082917697707.

Marler, T.E. 2019. Repetitive pruning of Serianthes nursery plants improves transplant quality and post-transplant survival. Plant Signal. Behav. 14:E1621246, https://doi.org/10.1080/15592324. 2019.1621246.

Marler, T.E. 2021. Leaf elemental concentrations, stoichiometry, and resorption in Guam's coastal karst forests. Diversity (Basel) 13:545, https:// doi.org/10.3390/d13110545.

Marler, T.E. and R.M. Callaway. 2021. Talking with strangers: Improving Serianthes transplant quality with interspecific companions. Forests 12:1192, https://doi.org/10.3390/f12091192.

Marler, T.E., A.N. Cascasan, and J.H. Lawrence. 2015. Threatened native trees in Guam: Shortterm seed storage and shade conditions influence emergence and growth of seedlings. HortScience 50:1049-1054.

Marler, T.E., C. Musser, A.N.J. Cascasan, G.N. Cruz and B.E. Deloso. 2021. Adaptive management lessons for Serianthes nelsonii conservation. Horticulturae 7:43, https://doi.org/10.3390/horti culturae 7030043 .

Marler, T. and C. Musser. 2015. Potential stressors leading to seedling mortality in the endemic Håyun lågu tree (Serianthes nelsonii Merr.) in the island of Guam. Trop. Conserv. Sci. 8:738-744. 